\title{
A COMPUTER ANALYSIS OF THE SPREAD OF POLLUTION ON LONG ISLAND BEACHES
}

\author{
ARTHUR G. TINGLE
}

July 1976

ATMOSPHERIC SCIENCES DIVISION DEPARTMENT OF APPLIED SCIENCE

BROOKHAVEN NATIONAL LABORATORY ASSOCIATED UNIVERSITIES, INC.

UNDER CONTRACT NO. EY-76-C-02-0016 WITH THE

UNITED STATES ENERGY RESEARCH AND DEVELOPMENT ADMINISTRATION

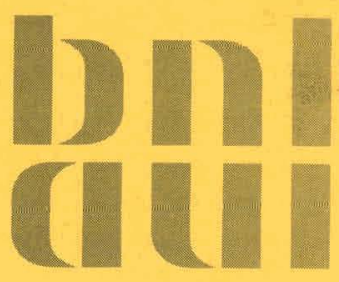




\section{DISCLAIMER}

This report was prepared as an account of work sponsored by an agency of the United States Government. Neither the United States Government nor any agency Thereof, nor any of their employees, makes any warranty, express or implied, or assumes any legal liability or responsibility for the accuracy, completeness, or usefulness of any information, apparatus, product, or process disclosed, or represents that its use would not infringe privately owned rights. Reference herein to any specific commercial product, process, or service by trade name, trademark, manufacturer, or otherwise does not necessarily constitute or imply its endorsement, recommendation, or favoring by the United States Government or any agency thereof. The views and opinions of authors expressed herein do not necessarily state or reflect those of the United States Government or any agency thereof. 


\section{DISCLAIMER}

Portions of this document may be illegible in electronic image products. Images are produced from the best available original document. 


\title{
A COMPUTER ANALYSIS OF THE SPREAD OF POLLUTION ON LONG ISLAND BEACHES
}

\author{
ARTHUR G. TINGLE
}

July 1976

ATMOSPHERIC SCIENCES DIVISION DEPARTMENT OF APPLIED SCIENCE
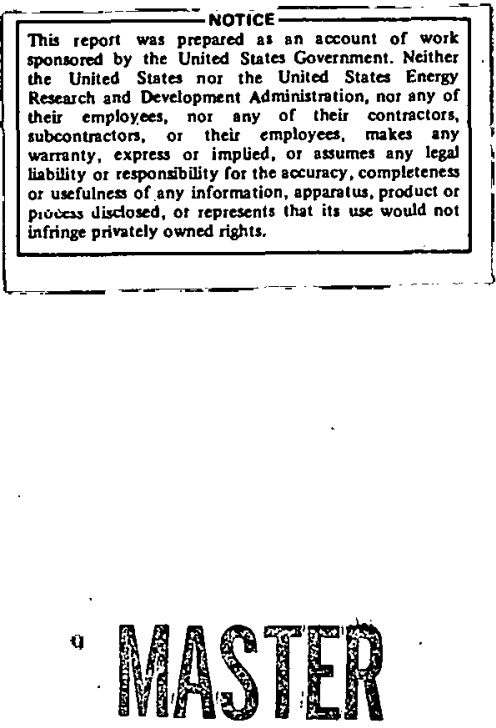

BROOKHAVEN NATIONAL LABORATORY

ASSOCIATED UNIVERSITIES, INC.

UPTON, NEW YORK 11973 
N O T I C E

This report was prepared as an account of work sponsored by lle United \&tatea Government. Neither the United States nor the United States Energy Research and Development Administration, nor any of their employees, nor any of their contractors, subcontractors, or their employees, makes any warranty, express or implied, or assumes any legal hability or reeponsibilicy fiu liti, sicuracy. completeness nr usefilness of any information, apparatus, product or process disclosed, or represents that its use would not infringe privatcly owned rights.

Printed in the United States of America Available from

National Technical Information Service

U.S. Department of Commerce 5285 Port Royal Road

Springfield, VA 22161

Price: Printed Copy $\$ 3.50$; Microfiche $\$ 3.00$

May 1977

400 copies 
A Computer Analysis of the Spread of Pollution

on Long Island Beaches

\begin{abstract}
In June 1976 large quantitles of garbage and sewage-type debris were washed ashore on most southern Long Island beaches. The floatable debris, of unknown source, threatened industry and public health. In an effort to trace the source, the trajectories of floatables from a variety of hypothetical release points in the New York Bight were simulated using a one-layer ocean model that computes currents, given the bottom topography and the observed winds. It was then assumed that the surface material moves as the vector sum of the currents and $3 \%$ of the wind. It was found that the initial beaching was probably due to debris floating in the Bight Apex, and that material from as far south as Atlantic City could have washed ashore during late June. An examination of historical wind records indicated that the persistent southwest winds observed during this perind could recur about each three years.
\end{abstract}


A Computer Analysis of the Spread of Pollution

Long Island Beaches

Arthur G. Tingle

Brookhaven National Laboratory

Upton, New York 11973

\section{Introduction}

A computer model originally used at Brookhaven in the Regional Energy Studies Program for assessing hazards to coastal regions from offshore petroleum activities was used to simulate trajectories of floating debris from a variety of hypothetical source regions in the New York Bight. The area modeled extended from south of Atlantic City to east of Montauk Point. The details of the model are available from the author. Basically, it is a one-layer model that computes currents using the topography of the area and observed winds as the driving force. It does not include a "background" pressure force that causes a sluggish drift to the southwest of a few centimeters per second. It is assumed that the surface material moves as the vector sum of the current speed and $3 \%$ of the wind speed, although the material could be moving at $2-5 \%$ of the wind speed. Nevertheless, comparisons with drift card data and current meter measurements indicate that for material released south of Long Ioland that impacts the beaches, within a few days, the model results could be accurate within one day and 15 kilometers. For material released within 25 kilometers of Sandy Hook with travel times of 10 days, the error could exceed 3 days because of the high frequency variability of currents and the effect of the Hudson River. Several model results for this region must be rejected because the confidence limits are unknown. 
The complexity of the mechanisms involved in the transport and fate of the variety of debris found on the beaches cannot at present be simulated in detail and the effects of waves, tides and estuarine discharges were not computed. In addition, because the ocean is stratified during the summer, the model could not be used to simulate the transport of material deposited on the ocean floor.

The model serves as a useful tool for posing a large variety of questions and for selecting situations and events that merit further analysis with more comprehensive physical reasoning. Therefore, the results discussed later will be presented in terms of our confidence in the model's performance under varying circumstances.

The following questions were posed to the model:

- From assumed distributions at sea, what are the landing limits (dispersion cones), times, and probabilities associated with the wind history following the reversal from predominately northerly to predominately southerly directions (thls occurred on the afternnon of June 6 )?

- Assuming Hudson Estuarine sources, what distribution of material would be expected in the Bight at the time of wind reversal and the subsequent fate of such material?

- Assuming that a pulse of material from the Bay Park explosion was rèledsed through East. Rockaway Inlet during Ebb Tide (00 - 0700 EST), what was the fate of such material?

- Assume that the spoils from the clean-up operations of the Bay Park explusion were deposited at the sewage sludge dump site, what is the fate of the surface material dumped (clean-up began June 3)? 
We also examined the historical wind records at Brookhaven National Laboratory in order to see if there was anything particularly unusual about the meteorological situation that could have contributed to the severity of the beaching of floatable material on the Long Island beaches.

We used the observed 10 meter hourly winds from a BNL tower at Tiana Beach, just west of Shinnecock Inlet, both to drive the model and to compute the surface transport. The wind data is plotted as daily transport (KM/day) in Figure 1. This figure indicates that around June 6-7 and June 12-13 wind shifts occurred that would reduce the reliability of the model, since the data may not be representative of the true wind pattern 'over the entire New York Bight. The latter period, unfortunately, is when the fouling of the beaches began, but we have not yet obtained more comprehensive data.

The method of calculation was to scatter 45 hypothetical continuous sources south of Long Island, down the Jersey shore, and in the Bight Apex. Tagged particle releases were simulated each four hours from each. source from 00 EST June 1 through June 28, which resulted in a data base of 7560 particles. A "hit" was counted if a particle came within $2 \mathrm{~km}$ of the shore and the particle was then frozen at that location, that is, the possibility that particles were floating alung the shore was not considered. In addition, particles were not allowed to impact the Jersey shore within $40 \mathrm{KM}$ of Sandy Hook.

The most striking feature of the results was the extreme variability of the currents throughout the period. We believe that this is real in the sense that nature behaves this way, but it also means that each trajectory must be treated as a statistic and not as an individual event. 
In fact, it may be impossible to trace the exact particle path from a source. Our examination of the computer results to date, however, leads us to believe that this is not important, since all particles floating in a large area southeast of New York on June 3 and 4 impacted Fire Island in a week or so. We do not see how the errors in the model could alter this conclusion. A few samples of the computer output should put the analys is in perspective.

Examples of the computed current patterns are shown in Figures 2 and 3 . On June 13 the currents were generally flowing to the southwest except for a clockwise gyre in the Bight Apex. However, by June 15, the pattcrn had completely reversed, with currents along the south shore of Long Island flowing to the east at about $10-15 \mathrm{~cm} / \mathrm{sec}$. These figures illustrate the variability discussed above and also the scale of the computer resolution. The grid spacing is $5.6 \mathrm{KM}$ with $\mathrm{N}$. Y. at the upper left and the shelf break at lower right. Examples of the computed trajectories are shuwn in Figures 4 and 5. Particles floating in the Apex at 00 EST Juns 5 rirculated around to impact Fire Island about Juile 11. Ḧowever, sume material would have missed the Island altogether. The picture is quite different on June 21 . Here, particles close to Long Island impacted within a day and particles $80 \mathrm{KM}$ south could have hit Fire Island within 5 days.

II. Analysis of Results

Assumed Sea Distributions

The results are summarizcd in Figure 6. The code for the plot is at the upper right. The times shown are hours from 00 EST June 1. Anything floating in the shaded area from June 1 to June 24 would have hit Long Island. The travel times are interesting in that even for sources close 
to shore the times range from less than one to more than ten days, although $90 \%$ hit within three days. The release times of particles that hit also varied over a wide range. For example, nothing released at the position southwest of Montauk Point before June $12 \mathrm{~h}$ it the Island, but then $71 \%$ impacted. The percentages shown refer only to the particles released during the indicated interval. The dispersion cones were too wide to plot, but even particles released at closer positions were scattered over about $1 / 3$ of the Island. This will be discussed in more detail below.

Another way of summarizing the results is shown in Figure 7 . All hits for each 12-hour period from all points are plotted against the 12 hour resultant Winds. The hits prior to June 6 were those released near the Jersey coast that hit New Jersey. The hits around the 8 th were those that were released after June 5. The hits beginning June 9 and 10 were those released on June 1-4. The break at June 12 is very important. We noted previously that the model winds may not be representative of those over the Bight. Since the observations were taken on the eastern end of Long Island the winds could have shifted a day later than at New York. This would have kept the particles released on June 1-4 floating for another day. During the period June 14-25, particles from nearly all sources were hilting with short travel times. The figure also shows that the problem dissipated after June 26 , even though particles were still being released. These plots were done for each release point and could be restricted to any area of the coast.

\section{Sludge Dump Site}

All particles released from the afternoon of June 2 through June 23 in the vicinity of the sludge dump site landed on the south shore of Long Island, scattered from East Rockaway Inlet to Watch Hill. Material 
released on June 3 landed on à line 30 kilometers long from Sailors Haven east on June 10 and 11. Material released on June 4-7 arrived earlier, mostly before June 9 and tended to concentrate near Sailors Haven. Material released on June 11-17 landed on Jones Beach within 1-2 days. Material released after this landed from East Rockaway Inlet to Fire Island Inlet within 1-3 days: The model results indicate that floating material at the dump site in early June could have circulated for 7-10 days before impacting Fire Island. Because of the short travel distances and times from mid-June on, we do not believe that the model is seriously in error during this period. Thus, if floating material was at the dump site during this period, it should have been found closer to New York. For the entire period about $40 \%$ of the material released near the dump site impacted Fire Island.

\section{The Bay Park Explosion}

Possible paths from East Rockaway Inlet into the ocean could not be tracked. Instead, releases were made at 20 points in a $300 \mathrm{kM}^{2}$ area. All the particlcc released uil Junc 3 anr 4 ended up ccattered along Fire Island in a week or so. For example, all partelce from. a release point $7 \mathrm{KM}$ southwest of the Inlet landed within $15 \mathrm{KM}$ of Sailors Haven on June 9 and 10. The uncertainties in an interpretation of this kind of detail are large, as discussed in the introduction. The particles were floating down the Jersey coasl for a couple of days and took 5 or 6 days after the wind shift to reach Fire Island. Thus many ut the pustirlce were floating in the area of the "no hit" boundary condition. The trajectories look smooth, so it 1s possible that the wind transport was dominating the current variability. The model results imply that a more comprehensive analysis is required. 


\section{The Hudson Estuary}

The model says that material at the time of the wind reversal was scattered down the Jersey coast and in a large area of the Bight Apex. Particles released on June 3 and 4 impacted Fire Island in a week or so. Particles released after this hit the city beaches. Since this did not happen, the model cannot be used with any credibility for Hudson Estuarine sources without additional information on transport out of the estuary.

III. The Meteorological Analysis

Thirteen previous years of hourly wind data from the $355^{\prime}$ Ace Tower at Brookhaven National Laboratory were analyzed for persistence to see if there was anything particularly rare about June 1976. Briefly, the situation prior to June 14 was not found to be particularly infrequent. However, during the period June 13 - 26 the winds had a steadiness that occurred only four times in the thirteen year sample.

Frequency distributions of

1) direction vs. the steadiness of the wind speed,

2) direction vs. the wind speed,

3) direction vs. the steadiness of the stress,

4) direction vs. stress

were calculated for $3,6,12,18$, and 24-day averages. In computing an " $N$ " day period, a new " $\mathrm{N}$ " day was computed every day. The steadiness is the ratio of the vector wind and the wind speed summed for each hour of the period. (A mathematical transformation was used here in order to give enhanced resolution near unity.) If the vectors are random its value is zero, and if there is no change its value is one. The stress is the 
mean of the square wind speed and is a measure of the strength of the wind to drive currents.

We selected the 6 and 12 day "steadiness of the stress" for illustration. Seven years of summer data are summarized in Table 1 . The winds are generally southwesterly over $60 \%$ of the time and a six-day steadiness of up to 0.7 is not unusual. The results for June 1976 are shown in Table 2. The steadiness did not reach a high value until June 18 and then it remained high through the 25th. The 12-day steadiness is shown in Table 3 for the dates of similar events in the past. The events are not independent. For example, in June 1967, the steadiness remained above 0.7 for 4 days in a row. It is interesting that July 1975 was "worse" than June 1976. We are not aware of any problem with the beaches either then, or for the other three cases. 
Table 1. Six-day Steadiness of the Stress for Seven Years of Summer (SSW through WSW direction).

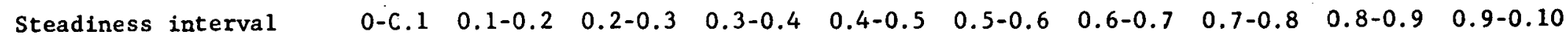

Percent Dccurrence

$\begin{array}{llll}1.2 & 5 & 11 & 15.8\end{array}$

13

8.3

4.4

0.8

0.5

0.3

Total Percent of All Directions - $60.3 \%$ 
Table 2. Six-day Steadiness of the Stress for June 1976.

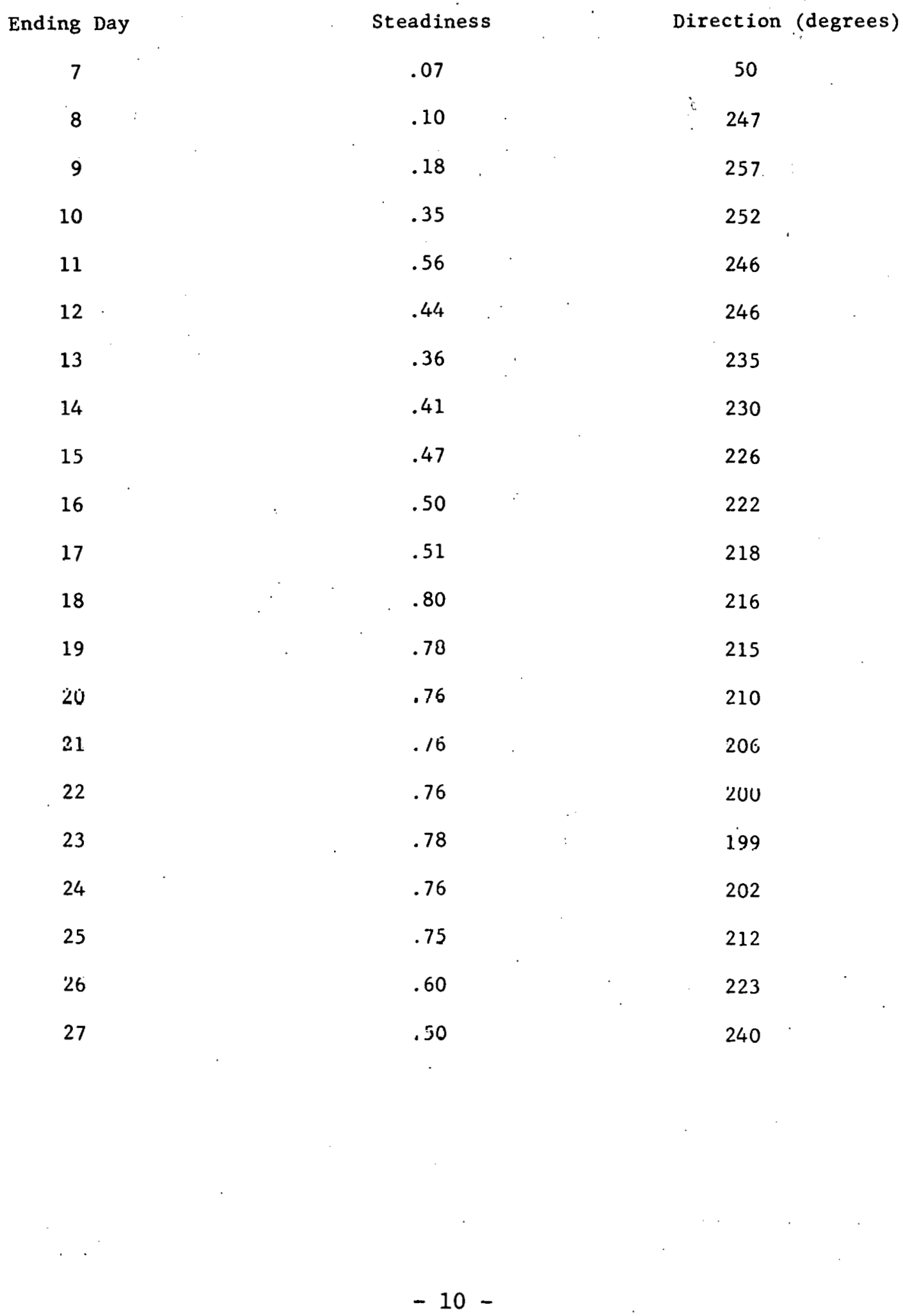


Table 3. Southwest Events with 12-day Steadiness of the Stress Greater than 0.7 (not independent).

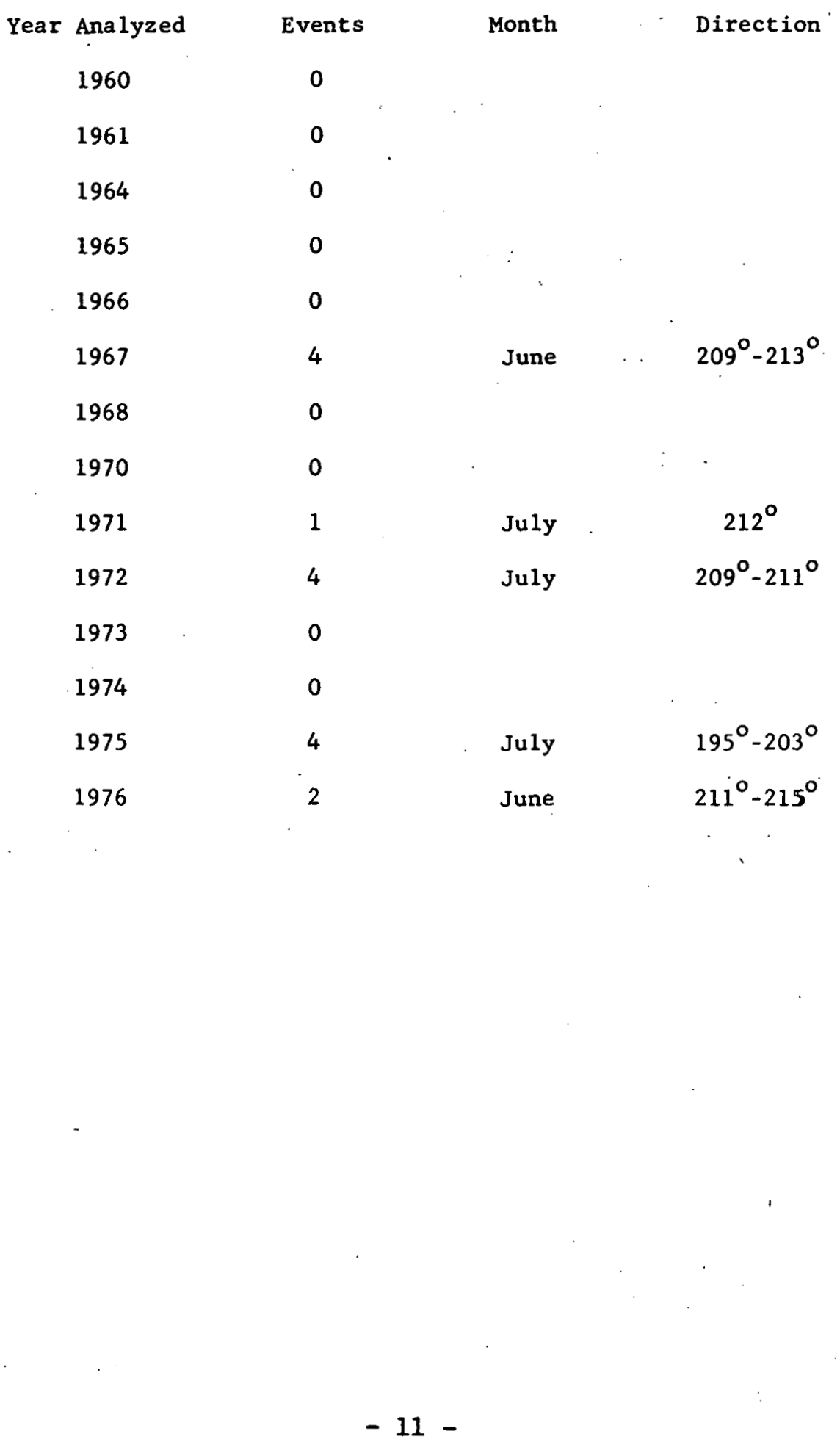


TRANSPORT - KM

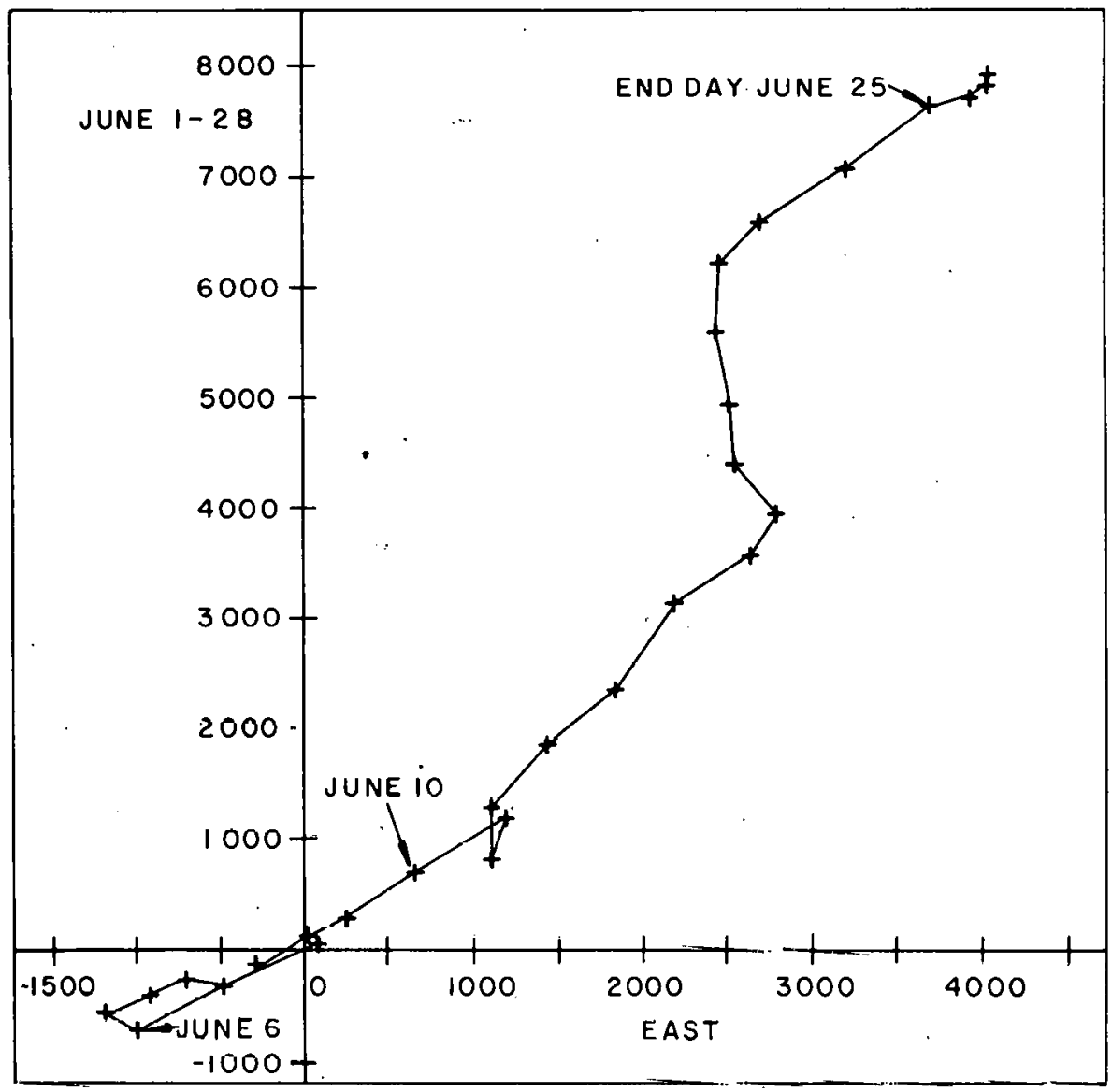

Figure 1. Total wind transport for each day as observed at 10 meters at Tlana Beach (Eastern Long Island). Each day is marked with a + . 
CURRENT AT 13.0O DAYS QR 2B3.00 HBURS

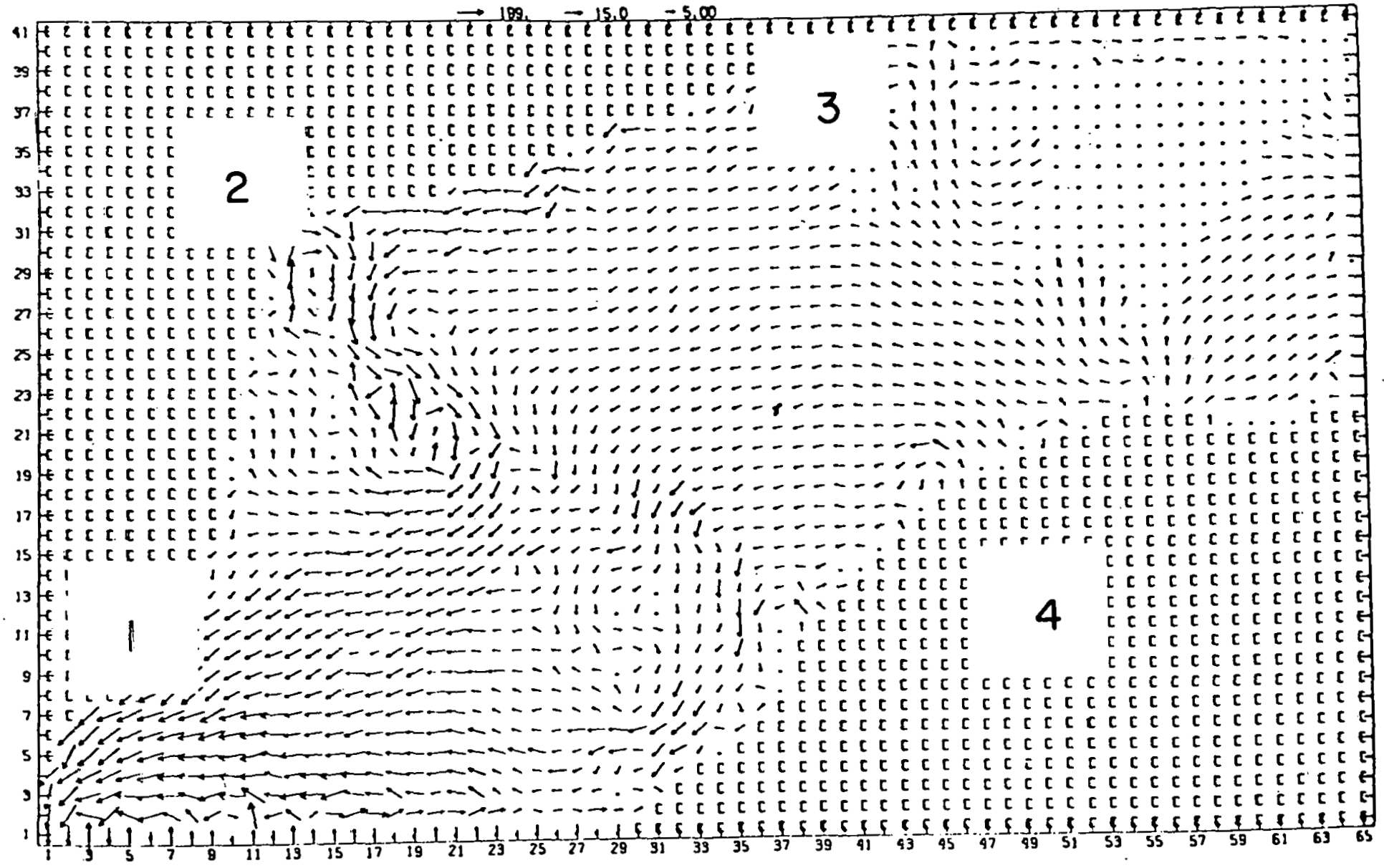

Figure 2. Computed currents on June 13 showing a southwest flow with a clockwise gyre near New York.

The locations are 1) Atlantic City, 2) New

York, 3) Montauk Point and, 4) deep ocean. 


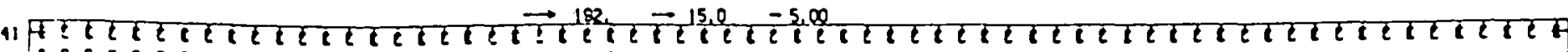

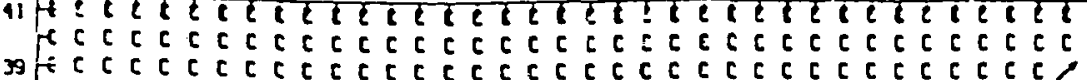

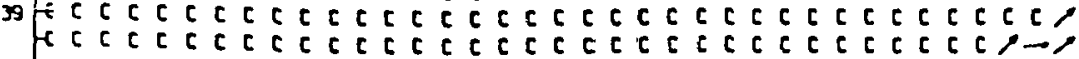

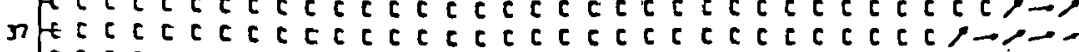

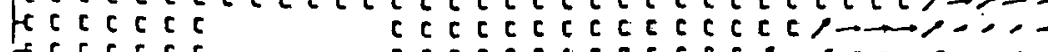

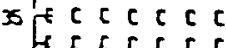

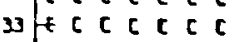

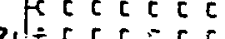

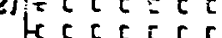

2

c t c c c c c c t c c c c c c c c c

3

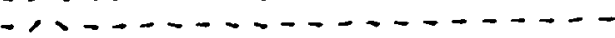
年 B.

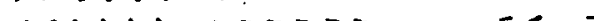

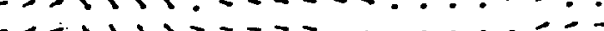
c c c c c c c

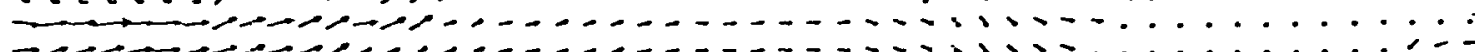
10

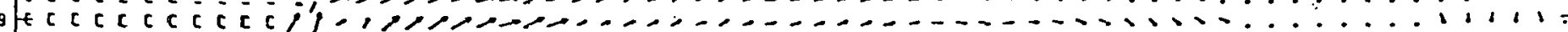
ectectectcec

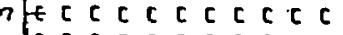

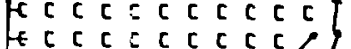

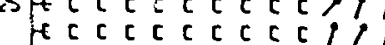

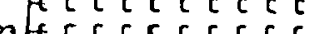

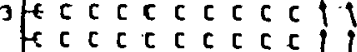

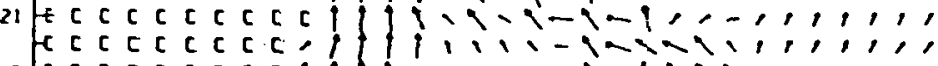

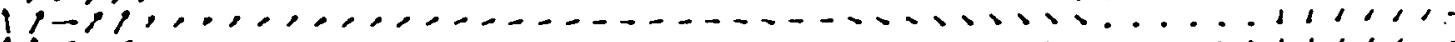

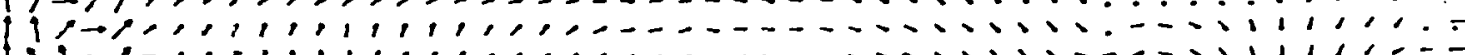

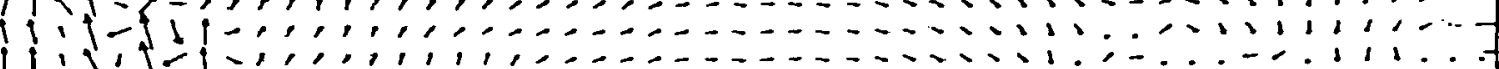

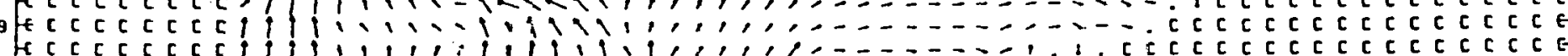

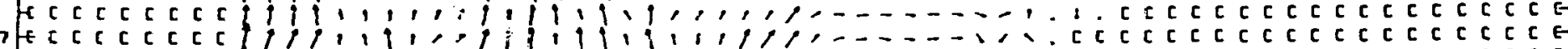

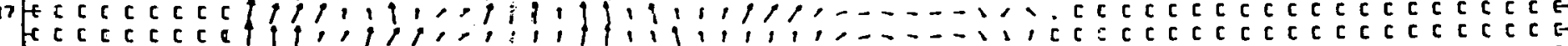

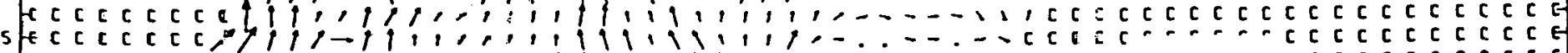

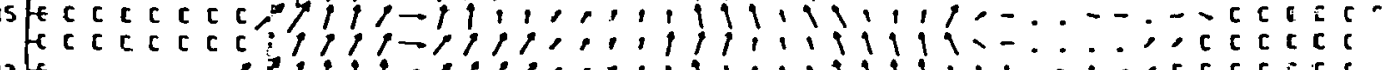
13 e cecces,

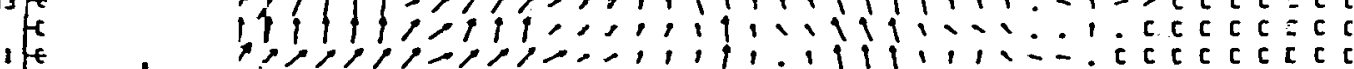
"

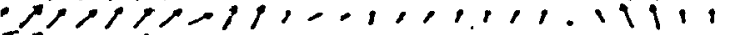

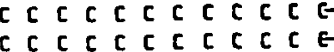

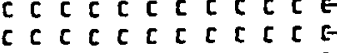

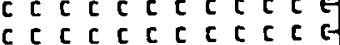

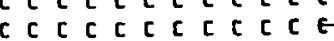
年,

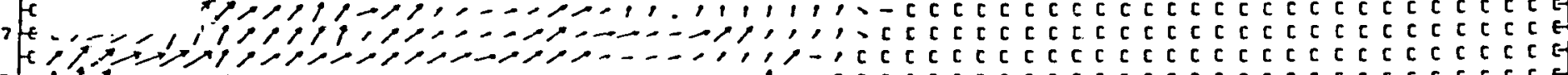
(l)

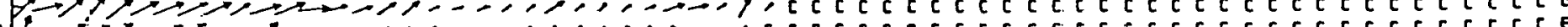
然

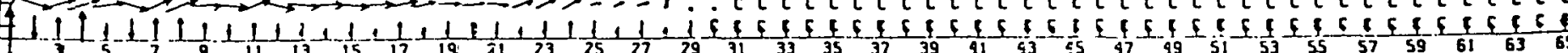

Figure 3 - Computed currents on June 15 . The flow has changed to easterly. Locations are the same as in Figure 2. 
TRAJECTORIES-STARTINC AT DAY 5

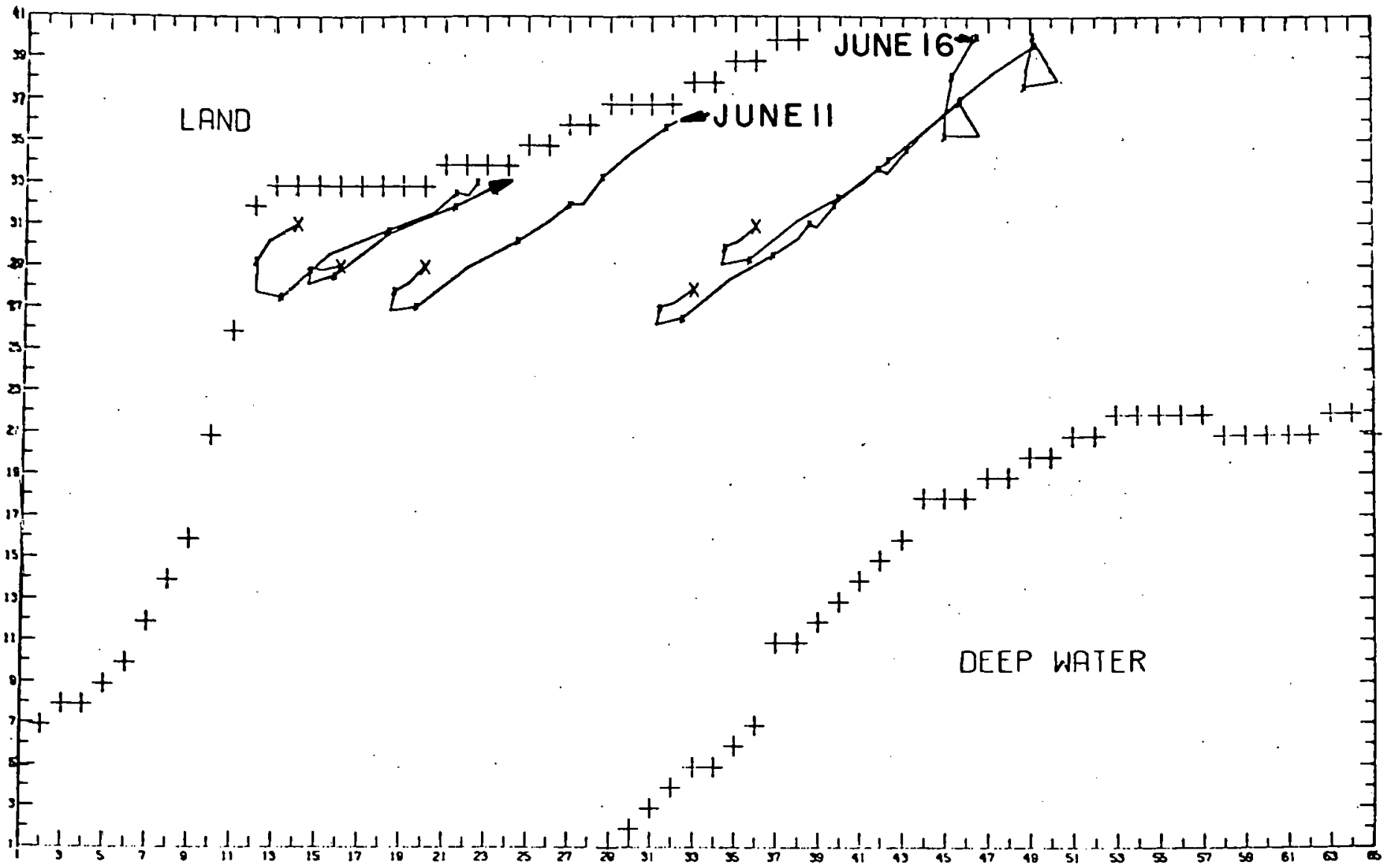

Figure 4. Hypothetical trajectories starting 00 EST June 5 for sample release points. Each day is marked with a + . 


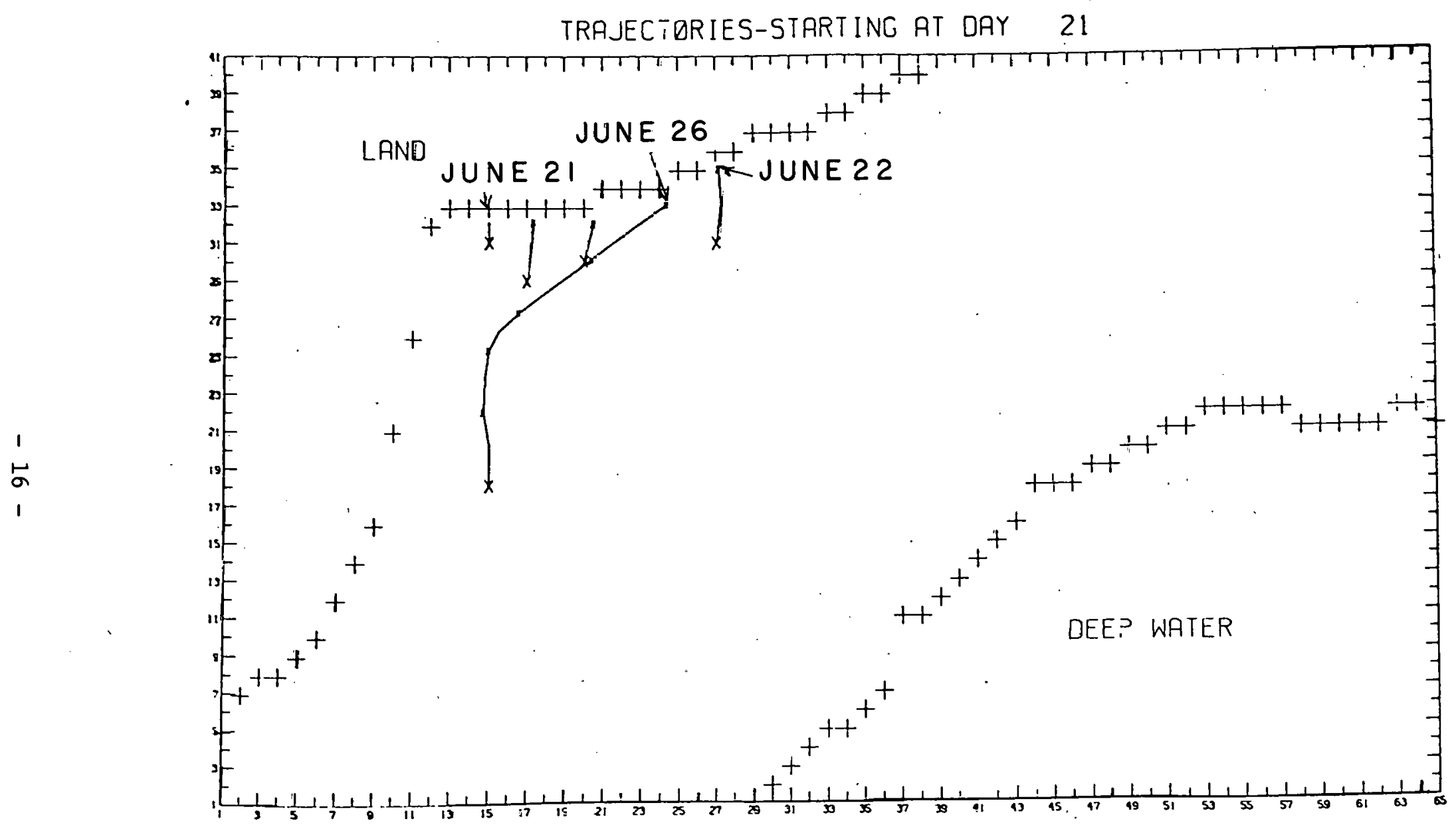

Figure 5. Hypothetical trajectories starting 00 EST

June 21. Floatable $80 \mathrm{KM}$ south of New York

could have hit Fire Island in 5 days. 


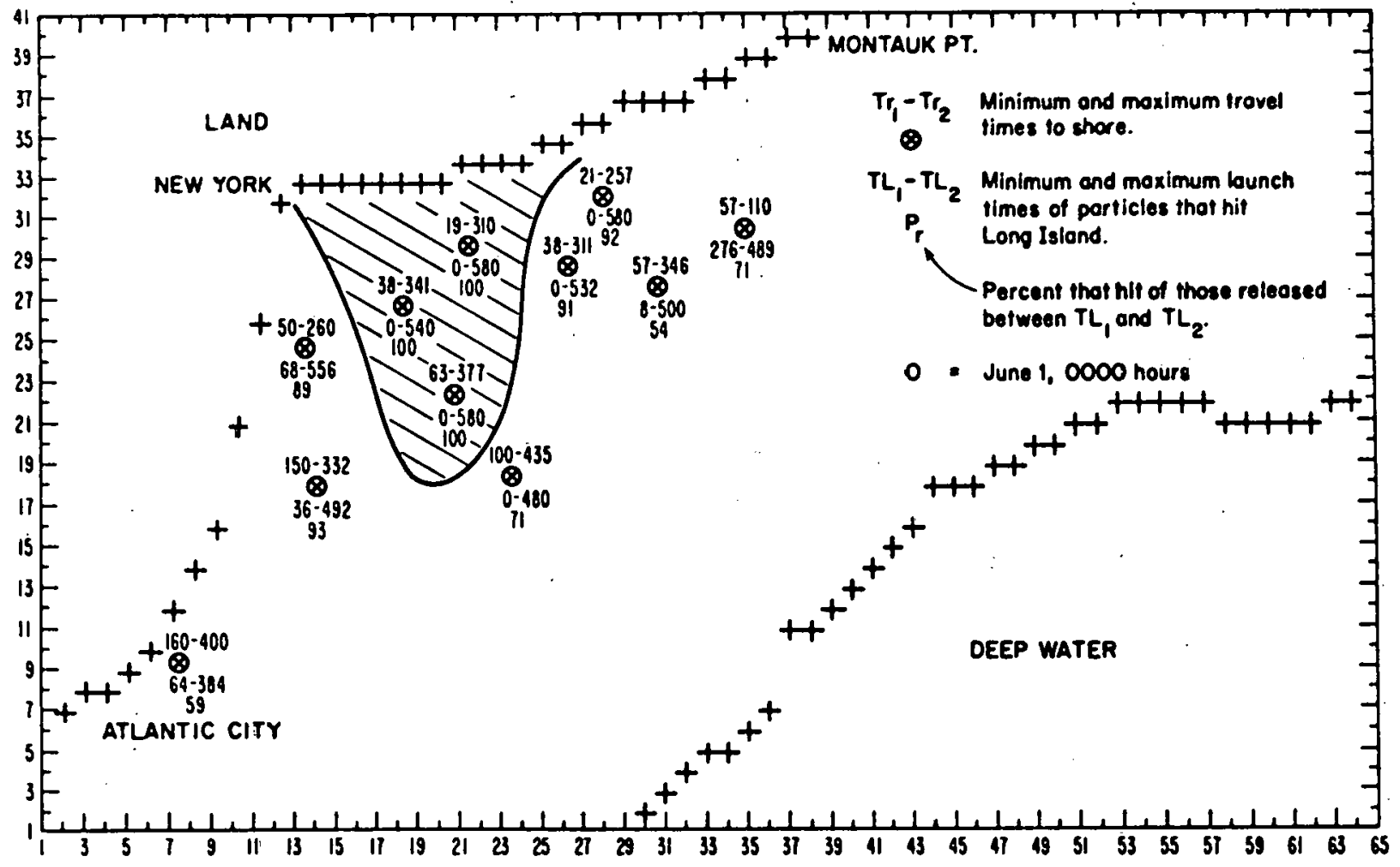

Figure 6. A statistical summary of all trajectories for 11 of the 45 release points. Time is in hours for 00 EST June 1 . The code is at the upper right. 


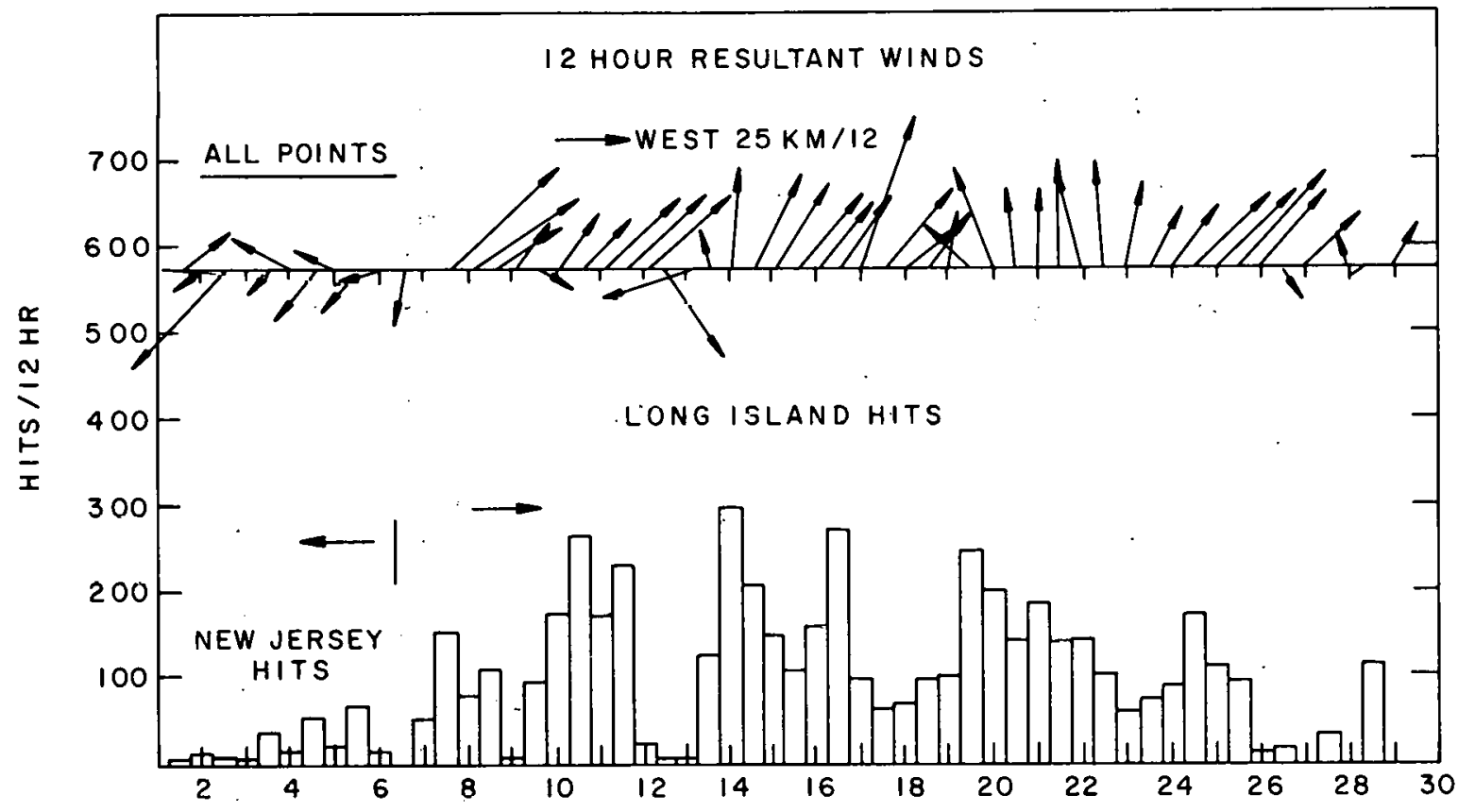

Figure 7. A summary of all hits from all locations plutted against the wind vector. The interpretation of this figure is discusjod in the text. 